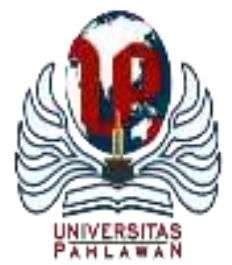

Edukatif : Jurnal Ilmu Pendidikan Volume 3 Nomor 6 Tahun 2021 Halm 5116 - 5125

EDUKATIF: JURNAL ILMU PENDIDIKAN

Research \& Learning in Education

https://edukatif.org/index.php/edukatif/index

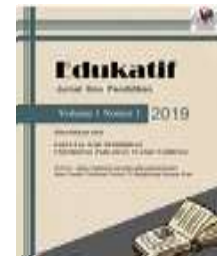

\title{
Kontribusi Pengalaman Mengajar dan Keterampilan Mengajar terhadap Kinerja Guru Pendidikan Agama Islam
}

\author{
Syariva 'Aini ${ }^{1 凶}$, Risdoyok ${ }^{2}$, Junaidi ${ }^{3}$ \\ Institute Agama Islam Negeri (IAIN) Bukittinggi, Indonesia ${ }^{1,2,3}$

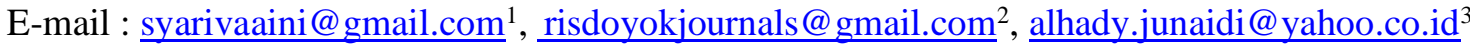

\begin{abstract}
Abstrak
Permasalahan dalam penelitian ini adalah kurang baiknya Kinerja Guru PAI SD se Kota Padang Panjang sehingga mengakibatkan belum terpenuhinya tugas pokok dan fungsi guru PAI SD se Kota Padang Panjang. Tujuan yang ingin dicapai dalam penelitian ini adalah untuk mengungkapkan berapa besar kontribusi Pengalaman Mengajar dan Keterampilan Mengajar Terhadap Kinerja Guru PAI SD se Kota Padang Panjang. Metode yang digunakan dalam Penelitian ini adalah metode kuantitatif. Hasil penelitian ini adalah terungkapnya: (1) Terdapatnya Kontribusi Pengalaman Mengajar terhadap Kinerja Guru PAI SD se Kota Padang Panjang, adapun besarnya Kontribusi Pengalaman Mengajar terhadap Kinerja Guru PAI SD se Kota Padang Panjang adalah 0.517 dengan koefisien determinasi sebesar 0.2673 atau (26,73 \%) (2) terdapat Kontribusi Keterampilan Mengajar Terhadap Kinerja Guru PAI SD se Kota Padang Panjang, Kinerja Guru PAI SD se Kota Padang Panjang ditentukan oleh Keterampilan Mengajar adalah 0.351 dengan koefisien determinasi sebesar 0.1232 atau $12.32 \%$. (3) Kontribusi Pengalaman Mengajar dan Keterampilan Mengajar secara bersama-sama terhadap Kinerja Guru PAI SD se Kota Padang Panjang, dan Kinerja Guru PAI SD se Kota Padang Panjang ditentukan oleh Pengalaman Mengajar dan Keterampilan Mengajar secara bersamasama adalah 0.752 dengan koefisien determinasi sebesar 0.5655 atau $56.55 \%$.
\end{abstract}

Kata Kunci: Pengalaman Mengajar, Keterampilan Mengajar, Kinerja Guru

\begin{abstract}
The problem in this study is the poor performance of PAI elementary school teachers in Padang Panjang City, resulting in the unfulfillment of the main tasks and functions of PAI elementary school teachers in Padang Panjang City. This research aims to reveal how much the contribution of Teaching Experience and Teaching Skills to the Performance of PAI Elementary School Teachers in Padang Panjang City. The method used in this study is quantitative. The results of this study are: (1) There is a contribution of teaching experience to the performance of PAI elementary school teachers in Padang Panjang City, while the amount of teaching experience contribution to the performance of PAI elementary school teachers in Padang Panjang is 0.517 with a coefficient of determination of 0.2673 or (26.73\%) (2) there is a contribution of teaching skills to the performance of PAI elementary school teachers in Padang Panjang City, the performance of PAI elementary school teachers in Padang Panjang City is determined by teaching skills is 0.351 with a coefficient of determination of 0.1232 or $12.32 \%$. (3) The contribution of teaching experience and teaching skills together to the performance of PAI elementary school teachers in Padang Panjang City, and the performance of PAI elementary school teachers in Padang Panjang city is determined by teaching experience and teaching skills together is 0.752 with a coefficient of determination of 0.5655 or $56.55 \%$.
\end{abstract}

Keywords: Teaching Experience, Teaching Skills, Teacher Performance.

Copyright (c) 2021 Syariva 'Aini, Risdoyok, Junaidi

$\square$ Corresponding author:

Email : syarivaaini@gmail.com

DOI : https://doi.org/10.31004/edukatif.v3i6.1645

ISSN 2656-8063 (Media Cetak)

ISSN 2656-8071 (Media Online)

Edukatif : Jurnal Ilmu Pendidikan Vol 3 No 6 Tahun 2021 p-ISSN 2656-8063 e-ISSN 2656-8071 


\section{Kontribusi Pengalaman Mengajar dan Keterampilan Mengajar terhadap Kinerja Guru Pendidikan Agama Islam - Syariva 'Aini, Risdoyok, Junaidi \\ DOI: https://doi.org/10.31004/edukatif.v3i6.1645}

\section{PENDAHULUAN}

Kinerja guru menjadi tolak ukur dari keberhasilan proses belajar dan mengajar disamping minat dan kemauan siswa yang tinggi. Kinerja guru yang baik memberikan kesan dan suasana yang nyaman dalam proses belajar dan mengajar. Menurut Smith yang dikutip oleh Mulyasa, mengatakan "Kinerja adalah merupakan hasil atau keluaran dari suatu proses".(Mulyasa, 2007) Selanjutnya Hasibuan memberikan pengertian "Kinerja atau prestasi kerja adalah suatu hasil kerja yang dicapai seseorang dalam melaksanakan tugas yang dibebankan kepadanya yang didasarkan atas kecakapan, pengalaman, dan kesungguhan serta waktu.".(Hasibuan, 2008) Dari beberapa pendapat di atas dapat ditarik kesimpulan bahwa yang dimaksud dengan kinerja guru adalah hasil kerja atau kemampuan kerja yang dapat dicapai oleh seorang guru yang sesuai dengan tanggung jawabnya dalam rangka mencapai tujuan organisasi yang bersangkutan.

Menurut Rivai kinerja merupakan terjemahan dari kata performance yang didefinisikan sebagai hasil atau tingkat keberhasilan seseorang secara keseluruhan selama periode tertentu untuk melaksanakan tugas dibandingkan dengan berbagai kemungkinan, seperti standar hasil kerja, target atau sasaran atau kriteria yang telah ditentukan terlebih dahulu dan telah disepakati bersama.(Rivai, 2005) Pendapat tentang kinerja guru tersebut di atas senada dengan AA Anwar P Mangkunegara, yang menyatakan bahwa kinerja (prestasi kerja) adalah hasil kerja secara kualitas dan kuantitas yang dicapai oleh seorang pegawai dalam melaksanakan tugasnya sesuai dengan tanggung jawab yang diberikan kepadanya.(Mangkunegara, 2009) Senada juga dengan pendapat Samsudin yang memberikan pengertian kinerja sebagai tingkat pelaksanaan tugas yang dapat dicapai seseorang dengan menggunakan kemampuan yang ada dan batasan-batasan yang telah ditetapkan untuk mencapai tujuan organisasi.(Sadili, 2006) Pendapat ini didukung oleh Nawawi yang memberikan pengertian kinerja sebagai hasil pelaksanaan suatu pekerjaan yang memberikan pemahaman bahwa kinerja merupakan suatu perbuatan atau perilaku seseorang yang secara langsung maupun tidak langsung dapat diamati oleh orang lain.(Nawawi Hadari, 2005) Pendapat senada juga dikemukakan oleh Mulyasa yang mendefinisikan kinerja sebagai prestasi kerja, pelaksanaan kerja, pencapaian kerja, hasil kerja atau unjuk kerja.(Mulyasa, 2004) Kinerja menunjuk pada ciri-ciri atau indikator sebagai berikut: Kinerja dalam suatu organisasi dapat dikatakan meningkat jika memenuhi indikator-indikator antara lain: kualitas hasil kerja, ketepatan waktu, inisiatif, kecakapan, dan komunikasi yang baik.

Kinerja guru dapat dikatakan baik jika guru telah melakukan unsur-unsur yang terdiri dari kesetiaan dan komitmen yang tinggi pada tugas mengajar, menguasai dan mengembangkan bahan pelajaran, kedisiplinan dalam mengajar dan tugas lainnya, kreativitas dalam melaksanakan pengajaran, kerjasama dengan semua warga sekolah, kepemimpinan yang menjadi panutan siswa, kepribadian yang baik, jujur dan objektif dalam membimbing siswa, serta tanggung jawab terhadap tugasnya. Guru harus mempunyai kesadaran, peran dan tanggung jawab dalam menjalankan tugas. Apabila kinerja guru tidak baik akan muncul permasalahan terhadap pihak manajemen sekolah, karena itu pihak manajemen sekolah perlu mengetahui faktor-faktor yang mempengaruhi kinerja guru. Faktor-faktor yang dapat mempengaruhi kinerja guru tersebut akan membuat manajemen sekolah dapat mengambil berbagai kebijakan yang diperlukan, sehingga dapat meningkatkan kinerja gurunya agar sesuai dengan harapan sekolah.

Kinerja guru Pendidikan Agama Islam masih tergolong rendah dan kurang baik, dimana dalam membuat perencanaan pembelajaran, Administrasi yang mereka buat lebih banyak Copy Paste, masih banyak guru-guru pendidikan agama islam yang membuat perencanaan pembelajaran asal ada dan cendrung masih copy paste, sehingga sering terjadi tidak kesesuaian antara materi yang ada di rencana pembelajaran dengan soal-soal latihan yang diberikan kepada siswa, dengan keadaan itu membuat evaluasi yang diberikan tidak berjalan dengan baik, dan hasil evaluasi siswa juga tidak ada tindak lanjutnya sehingga pembelajaran tidak berjalan dengan bermakna, Menurut salah seorang guru Pendidikan Agama Islam, yang penulis wawancarai, mengatakan bahwa kelengkapan Administrasinya pada umumnya merupakan copy paste dari teman sepropesi 


\section{Kontribusi Pengalaman Mengajar dan Keterampilan Mengajar terhadap Kinerja Guru Pendidikan Agama Islam - Syariva 'Aini, Risdoyok, Junaidi \\ DOI: https://doi.org/10.31004/edukatif.v3i6.1645}

di Kelompok Kerja Guru (KKG-PAI) mulai dari rencana pembelajaran, Program tahunan, program semester, KKM dan sebagainya, dan masih menurut pengakuannya semua itu dikarenakan kurang semangat dan kurang motivasinya dalam membuat sendiri serta kurangnya kemampuan untuk membuat perangkat pembelajaran sendiri.

Untuk meningkatkan kinerja guru perlu dilakukan beberapa upaya antara lain melalui pembinaan disiplin, pemberian motivasi, penghargaan dan persepsi. Sejalan dengan tantangan kehidupan global, peran dan tanggung jawab guru pada masa mendatang akan semakin kompleks, sehingga menuntut guru untuk senantiasa melakukan berbagai peningkatan penyesuaian penguasaan kompetensinya. Guru harus lebih dinamis dan kreatif dalam mengembangkan proses pembelajaran siswa.

Kinerja guru dapat juga dipengaruhi oleh berapa lama guru tersebut menggeluti profesinya sebagai guru, idealnya guru yang sudah lama berkecimpung dalam dunia Pendidikan tentu akan lebih baik kinerjanya.Pengalaman mengajar adalah masa kerja guru dalam melaksanakan tugas sebagai pendidik dalam hal-hal yang dialami dalam mengajar dan berkaitan dengan nilai- nilai kompetensi guru yang diharapkan dengan semakin berpengalaman guru mengajar maka kompetensi guru dalam mengajar juga baik.

Kinerja guru dalam penelitian ini diduga dipengaruhi oleh beberapa faktor antara lain intelegensi, sikap, kemampuan professional, ketrampilan menajemen, keamanan, suasana atau kerja tim, perencanaan, kepemimpinan dan pengawasan. Faktor-faktor tersebut sebagaimana dikemukakan oleh Siagian bahwa ada beberapa faktor yang dapat mempengaruhi kinerja antara lain: (1) Intelegensi, (2) Sikap, (3) Pengalaman/Kemampuan professional guru, (4) Ketrampilan menajemen, (5) Suasana atau iklim kerja sama (kerja tim), (6) Keamanan dan perlindungan kerja, (7) Perencanaan, (8) Pengawasan, (9) Motivasi internal, (10) kepemimpinan kepala sekolah.(Sondang P. Siagian, 2002)

Banyak penelitian yang telah dilakukan oleh peneliti terkait dengan kinerja guru ini, seperti penelitian oleh Via humairah di SMPN sekota Metro (2017), dengan hasil penelitian Pengalaman mengajar berhubungan positif dan signifikan dengan Kinerja Guru SMPN se Kota Metro sebesar 19,70 \%. Penelitian oleh Sri Hartini tentang " Pengaruh Keterampilan Mengajar dan Pengalaman Mengajar Terhadap Kinerja Kepala Sekolah Dasar Se Kecamatan Wiradesa Kabupaten Pekalongan ". telah diketahui bahwa Keterampilan Mengajar dan Pengalaman Mengajar mempunya pengaruh terhadap Kinerja kepala Sekolah. Selanjutnya penelitian tentang "Pengaruh Keterampilan Mengajar, Pengalaman, Penataran dan Kecerdasan Emosional terhadap Kinerja Kepala Sekolah SMU Negeri di Kediri” yang dilakukan oleh Siti Marwujah bahwa penelitian ini bermaksud mendeskripsikan pengaruh yang terdapat pada empat variabel, yakni variabel Keterampilan Mengajar ( $\mathrm{X}_{1}$ ), pengalaman penataran $\left(\mathrm{X}_{2}\right)$ dan Kecerdasan Emosional ( $\mathrm{X}_{3}$ ) terhadap Kinerja Kepala Sekolah ( $\mathrm{Y}$ ). Dari hasil perhitungan kecendrungan perfomansi mengajar diperoleh rerata skor 81,47 dan simpangan baku 5,9113. Angka korelasi yang diperoleh adalah 0,462 dengan taraf signifikan 0,05. Hasil ini apabila diuji dengan hanya koefisien korelasi pada tabel adalah lebih tinggi $(0,344<0,462)$. Dengan demikian dapat disimpulkan hipotesis yang menyatakan "Terhadap Pengaruh yang Signifikan Keterampilan Mengajar terhadap Kinerja Kepala sekolah SMU Negeri di Kediri” diterima. Angka korelasi yang diperoleh adalah 0,418. Harga koefisien ini lebih besar dari harga tabel pada taraf signifikan 0,05 yaitu 0,344. Dengan demikian hipotesis karya ilmiah yang ditanyakan "Terdapat Pengaruh yang Signifikan Kecerdasan Emosional terhadap Kinerja Kepala Sekolah SMU Negeri di Kediri” diterima.

Dari seluruh penelitian yang telah dilakukan di atas, tidak satupun penelitian yang membahas tentang Kinerja Guru Pendidikan Agama Islam, Oleh sebab itu Penelitian yang penulis lakukan ini sangat penting dilakukan, karena dengan adanya penelitian ini, akan terungkap bagamana kontribusi pengalaman mengajar dan Keterampilan Mengajar terhadap Kinerja Guru Pendidikan Agama Islam di SD. 
5119 Kontribusi Pengalaman Mengajar dan Keterampilan Mengajar terhadap Kinerja Guru Pendidikan Agama Islam - Syariva 'Aini, Risdoyok, Junaidi

DOI: https://doi.org/10.31004/edukatif.v3i6.1645

\section{METODE PENELITIAN}

Penelitian ini adalah penelitian kuantitatif melalui metode korelasional. Yang dimaksud dengan penelitian korelasional adalah penelitian yang bertujuan untuk mengukur tentang ada atau tidak adanya hubungan antara dua atau lebih dari variabel yang diajukan oleh peneliti dengan ukuran yang valid dan reliabel. Jenis ini dipilih karena jumlah populasi penelitian yang tidak terlalu banyak dan juga data yang akan dihasilkan berupa angka-angka.(Syahron, 2006). Metode korelasional dipilih karena penelitian bertujuan untuk mengungkapkan besarnya hubungan antara variabel yang satu terhadap variabel lainnya.(Suharsimi Arikunto, 1998). Lokasi penelitian ini adalah di SD se Kota Padang Panjang sebanyak 42 SD, yang terdiri 38 SDN dan 4 SD swasta. Waktu penelitian ini dilaksanakan selama 6 bulan yakni bulan Februari sampai bulan Juli tahun 2021.

Populasi dalam penelitian berjumlah 46 orang guru Pendidikan Agama Islam. Teknik pengambilan sampel dengan menggunakan tabel yang dikemukana oleh sugiono, yang langsung ada tabelnya, dimana pada tabel tersebut telah tersedia jumlah populasi dan jumlah sampel yang akan di ambil dengan taraf kesalahan $10 \%{ }^{1}$. Adapun jumlah sampel dalam penelitian ini adalah berjumlah 39 orang Guru Pendidikan Agama Islam yang tersebar di SD se Kota Padang Panjang. Untuk mendapatkan data dalam penelitian ini penulis menyebarkan angket kepada sampel yang telah ditentukan, instrument dalam angket tersebut menggunakan angket tertutup. Angket digunakan untuk mendapatkan data tentang bagaimana kontribusi pengalaman mengajar dan keterampilan mengajar terhadap kinerja guru Pendidikan Agama Islam.

\section{HASIL DAN PEMBAHASAN PENELITIAN}

\section{Kinerja Guru Pendidikan Agama Islam (Y).}

Jumlah butir angket dalam penelitian ini adalah 34 butir, sehingga skor maksimalnya 170. Skor variabel Kinerja Guru PAI SD Kota Padang Panjang menyebar antara 122 (minimum) dan 149 (Maksimum). Selanjutnya diperoleh skor rata-rata (mean) sebesar 134.08, skor tengah (median) sebesar 135.00, skor yang banyak muncul (mode) 124 dan simpangan baku (standard deviation) 7.534.

\section{Tabel 1}

Distribusi Frekwensi Data Kinerja Guru PAI SD Kota Padang Panjang

\begin{tabular}{ccccc}
\hline Kelas Interval & Frequency & Percent & Valid Percent & Cumulative Percent \\
\hline $122-126$ & 9 & 23.1 & 23.1 & 23.1 \\
$127-131$ & 5 & 12.8 & 12.8 & 35.9 \\
$132-136$ & 10 & 25.6 & 25.6 & 61.5 \\
$137-140$ & 7 & 17.9 & 17.9 & 79.5 \\
$141-149$ & 8 & 20.5 & 20.5 & 100.0 \\
Total & 39 & 100.0 & 100.0 & \\
\hline
\end{tabular}

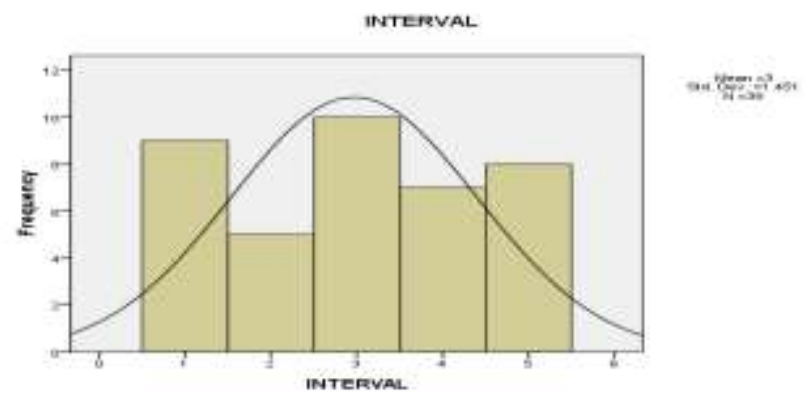

Gambar 1. Histogram Kinerja Guru Pendidikan Agama Islam (Y) 
5120 Kontribusi Pengalaman Mengajar dan Keterampilan Mengajar terhadap Kinerja Guru Pendidikan Agama Islam - Syariva 'Aini, Risdoyok, Junaidi

DOI: https://doi.org/10.31004/edukatif.v3i6.1645

Tabel 4.2. di atas menunjukkan bahwa skor Kinerja Guru PAI SD Kota Padang Panjang yang berada kelas interval rata - rata adalah $25.6 \%$, di atas kelas interval rata-rata $17.9 \%$ dan dibawah skor rata-rata 12.8 $\%$. Tingkat pencapaian skor Kinerja Guru adalah hasil bagi rata - rata dengan skor maksimum ideal, yaitu $134.08: 170 \times 100 \%=78,87 \%$ (termasuk kategori Cukup). Hasil ini menunjukkan bahwa Kinerja Guru PAI SD Kota Padang Panjang tersebut Cukup.

Tabel 2

Tingkat Pencapaian Responden per Indikator Kinerja Guru PAI SD Kota Padang Panjang

\begin{tabular}{lcccc}
\hline \multicolumn{1}{c}{ Indikator } & Skor Ideal & Rata-rata & $\begin{array}{c}\text { \% Tingkat } \\
\text { Pencapaian }\end{array}$ & Kategori \\
\hline a. Merencanakan Proses Pembelajaran & 55 & 43,36 & 78,83 & Cukup \\
b. Melaksanakan Proses Pembelajaran & 55 & 43,97 & 79,95 & Cukup \\
c. Mengevaluasi Proses Pembelajaran & 40 & 31,00 & 77,50 & Cukup \\
d. Melaksanakan tindak lanjut & 20 & 15,74 & 78,72 & Cukup \\
$\quad$ Keseluruhan Kinerja Guru & 170 & 134,08 & 78,87 & Cukup \\
\hline
\end{tabular}

Tingkat pencapaian skor Kinerja Guru PAI SD Kota Padang Panjang termasuk Cukup (78,87\%). Hasil ini menunjukkan bahwa Kinerja Guru PAI SD Kota Padang Panjang tersebut termasuk kategori Cukup baik.

Secara rinci dapat dijelaskan bahwa indikator pertama Kinerja Guru PAI SD Kota Padang Panjang adalah merencanakan proses belajar mengajar, dengan tingkat pencapaian 78,83\% atau Cukup, indikator kedua melaksanakan proses belajar mengajar, dengan tingkat pencapaian $79,95 \%$ atau Cukup, indikator ketiga mengevaluasi proses belajar mengajar, dengan tingkat pencapaian 77,50\% atau Cukup dan indikator keempat melaksanakan tindak lanjut, dengan tingkat pencapaian 78,72\% atau Cukup.

\section{Pengalaman Mengajar Guru PAI SD Kota Padang Panjang $\left(\mathbf{X}_{1}\right)$}

Data variabel Pengalaman Mengajar Guru PAI SD Kota Padang Panjang, diperoleh dari 32 butir pernyataan dengan jumlah skor 160. Skor variabel Pengalaman Mengajar Guru PAI SD Kota Padang Panjang menyebar antara 120 (Minimum) dan 144 (Maksimum). Selanjutnya diperoleh skor rata-rata (Mean) sebesar 127.05, skor tengah (Median) sebesar 126.00, skor yang banyak muncul (Mode) 126 dan simpangan baku (standard deviation) 4.888 .

Tabel 3

Distribusi Frekwensi Skor Variabel Pengalaman Mengajar Guru PAI SD Kota Padang Panjang

\begin{tabular}{ccccc}
\hline Kelas Interval & Frequency & Percent & Valid Percent & Cumulative Percent \\
\hline $120-124$ & 12 & 30.8 & 30.8 & 30.8 \\
$125-129$ & 18 & 46.2 & 46.2 & 76.9 \\
$130-134$ & 5 & 12.8 & 12.8 & 89.7 \\
$135-144$ & 4 & 10.3 & 10.3 & 100.0 \\
Total & 39 & 100.0 & 100.0 & \\
\hline
\end{tabular}

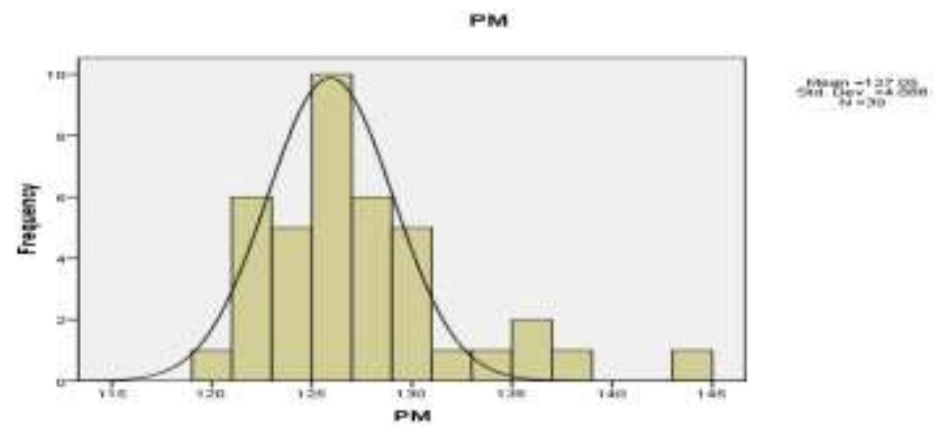

Gambar 2. Histogram Pengalaman Mengajar Guru PAI SD Kota Padang Panjang $\left(X_{1}\right)$ 
5121 Kontribusi Pengalaman Mengajar dan Keterampilan Mengajar terhadap Kinerja Guru Pendidikan Agama Islam - Syariva 'Aini, Risdoyok, Junaidi

DOI: https://doi.org/10.31004/edukatif.v3i6.1645

Tabel 4.4. di atas menunjukkan bahwa skor Pengalaman Mengajar yang berada kelas interval rata - rata adalah $46.2 \%$, di atas kelas interval rata-rata $30.8 \%$ dan dibawah skor rata-rata $12.8 \%$. Tingkat pencapaian skor Pengalaman Mengajar Guru PAI SD Kota Padang Panjang adalah hasil bagi rata - rata dengan skor maksimum ideal, yaitu 127,50: 160 x $100 \%=79,41 \%$ (termasuk kategori Cukup).

Tabel 4

Tingkat Pencapaian Responden perindikator Pengalaman Mengajar Guru Pendidikan Agama Islam

\begin{tabular}{|c|c|c|c|c|}
\hline Indikator & Skor Ideal & Rata-rata & $\begin{array}{l}\% \text { Tingkat } \\
\text { Pencapaian }\end{array}$ & Kategori \\
\hline a. Pengalaman Mengajar & 75 & 59,59 & 79,45 & Cukup \\
\hline b. Lama Mengajar & 20 & 15,62 & 78,08 & Cukup \\
\hline c. Peningkatan Profesionalisme & 65 & 51,85 & 79,76 & Cukup \\
\hline Keseluruhan Pengalaman Mengajar & 160 & 127,50 & 79,41 & Cukup \\
\hline
\end{tabular}

Secara rinci dapat dijelaskan bahwa indikator pertama Pengalaman Mengajar PAI SD Kota Padang Panjang adalah Pengalaman Mengajar, dengan tingkat pencapaian 79,45\% atau Cukup, indikator kedua Lama Mengajar, degan tingkat pencapaian 78,08 \% atau Cukup, indikator ketiga Peningkatan Profesionalisme, dengan tingkat pencapaian $79,76 \%$ atau Cukup.

\section{Keterampilan Mengajar Guru PAI SD Kota Padang Panjang $\left(\mathbf{X}_{2}\right)$}

Data variabel Keterampilan Mengajar Guru PAI SD Kota Padang Panjang diperoleh dari 25 butir pernyataan dengan skor idealnya 125. Skor variabel Keterampilan Mengajar Guru Pendidikan Agama Islam menyebar antara 92 (Minimum) dan 119 (Maksimum). Selanjutnya diperoleh skor rata-rata (mean) sebesar 97.67, skor tengah (median) sebesar 95.00, skor yang banyak muncul (mode) 92 dan simpangan baku (standard deviation) 6.956 .

\section{Tabel 5}

Distribusi Frekwensi Skor Variabel Keterampilan Mengajar Guru PAI SD Kota Padang Panjang

\begin{tabular}{ccccc} 
Kelas Interval & Frequency & Percent & Valid Percent & Cumulative Percent \\
\hline $92-96$ & 25 & 64.1 & 64.1 & 64.1 \\
$97-101$ & 7 & 17.9 & 17.9 & 82.1 \\
$102-106$ & 2 & 5.1 & 5.1 & 87.2 \\
$107-111$ & 2 & 5.1 & 5.1 & 92.3 \\
$112-119$ & 3 & 7.7 & 7.7 & 100.0 \\
Total & 39 & 100.0 & 100.0 &
\end{tabular}

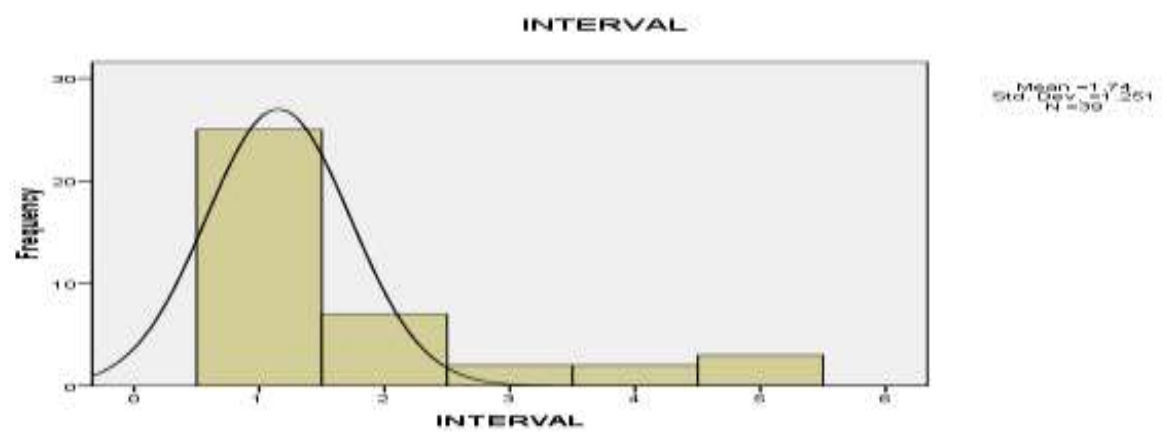

Gambar 3. Histogram Keterampilan Mengajar Guru PAI SD Kota Padang Panjang ( $\left.X_{2}\right)$ 
5122 Kontribusi Pengalaman Mengajar dan Keterampilan Mengajar terhadap Kinerja Guru Pendidikan Agama Islam - Syariva 'Aini, Risdoyok, Junaidi

DOI: https://doi.org/10.31004/edukatif.v3i6.1645

Tabel 4.6. di atas menunjukkan bahwa skor Keterampilan Mengajar PAI SD Kota Padang Panjang yang berada kelas interval rata-rata adalah $17.90 \%$, di atas kelas interval rata-rata $64.10 \%$ dan dibawah skor ratarata $5.10 \%$.

Tingkat pencapaian skor Keterampilan Mengajar Guru PAI SD Kota Padang Panjang adalah hasil bagi rata - rata dengan skor maksimum ideal, yaitu 97,67: 125 x $100 \%=78,13 \%$ (termasuk kategori Cukup). Hasil ini menunjukkan bahwa Keterampilan Mengajar Guru Pendidikan Agama Islam tersebut Cukup.

Tabel 6

Tingkat Pencapaian Responden per Indikator Keterampilan Mengajar PAI SD Kota Padang Panjang

Indikator Skor Ideal Rata-rata $\begin{gathered}\% \text { Tingkat } \\ \text { Pencapaian }\end{gathered}$ Kategori

\begin{tabular}{lcccc}
\hline a. Keterampilan Bertanya & 15 & 12,00 & 80,00 & Baik \\
b. Keterampilan memberikan Penguatan & 15 & 12,85 & 85,64 & Baik \\
c. Keterampilan mengadakan Variasi & 25 & 18,97 & 75,90 & Cukup \\
d. Keterampilan membuka dan menutup & 30 & 22,85 & 76,15 & Cukup \\
Pelajaran & 15 & 11,36 & 75,73 & Cukup \\
e. Keterampilan Menjelaskan & 25 & 19,64 & 78,56 & Cukup \\
f. Keterampilan mengelola Kelas & 150 & 118,47 & 78,98 & Cukup \\
\hline
\end{tabular}

Secara rinci dapat dijelaskan bahwa indikator pertama Keterampilan Mengajar PAI SD Kota Padang Panjang adalah menguasai karakteristik peserta didik, dengan tingkat pencapaian 80,00 \% atau Baik, indikator kedua Keterampilan memberikan Penguatan, degan tingkat pencapaian 85,64 \% atau Baik, indikator ketiga Keterampilan mengadakan Variasi, dengan tingkat pencapaian $75,90 \%$ atau cukup, indikator keempat Keterampilan membuka dan menutup Pelajaran, dengan tingkat pencapaian $76,15 \%$ atau Cukup, intikator kelima adalah Keterampilan Menjelaskan dengan tingkat pencapaian 75,73 \% atau Cukup dan Indikator ke enam adalah Keterampilan mengelola Kelas dengan tingkat pencapaian 78,56 \% atau Cukup.

\section{Hipotesis pertama}

Hipotesis pertama adalah "Pengalaman Mengajar berkontribusi secara positif dan Signifikan terhadap Kinerja Guru PAI SD Kota Padang Panjang”. Untuk menguji hipotesis ini digunakan analisa korelasi dan regresi sederhana. Pengujian hipotesis ini dilakukan dengan menggunakan hipotesa sabagai berikut :

$\mathrm{H}_{0} \quad=$ Tidak terdapat kontribusi yang positif dan signifikan antara Pengalaman Mengajar terhadap Kinerja Guru PAI SD Kota Padang Panjang.

$\mathrm{H}_{1} \quad=$ Terdapat kontribusi yang positif dan signifikan antara Pengalaman Mengajar terhadap Kinerja Guru PAI SD Kota Padang Panjang

Dasar pengambilan keputusan adalah bahwa diterima Ho jika nilai signifikasi > Alpha 0,05 atau $\mathrm{H}_{1}$ jika siknifikasi < Alpha 0,05.

Tabel 7

Rangkuman Hasil Analisis Korelasi $\mathbf{X}_{1}-\mathbf{Y}$

\begin{tabular}{lcccc}
\hline Korelasi & $\mathrm{N}$ & Koefisien Korelasi (r) & Koefisien Determinasi $\left(\mathrm{r}^{2}\right)$ & Sig. \\
Ry1 & 39 & .517 & .2673 & $.000^{\mathrm{a}}$ \\
\hline
\end{tabular}

Dari hasil analisis diperoleh angka koefisien variabel Pengalaman Mengajar dengan variabel Kinerja Guru PAI SD Kota Padang Panjang (ry1) sebesar 0.517. Angka korelasi ini menunjukkan bahwa kontribusi Pengalaman Mengajar terhadap Kinerja Guru PAI SD Kota Padang Panjang berkorelasi positif. Selanjutnya tabel memperlihatkan angka koefisien determinasi sebesar 0.2673 dengan signifikasi sebesar 0.000. Sesuai dengan pengambilan keputusan di atas maka $\mathrm{Ho}$ ditolak dan $\mathrm{H}_{1}$ diterima. Ini berarti terdapat kontribusi yang 
5123 Kontribusi Pengalaman Mengajar dan Keterampilan Mengajar terhadap Kinerja Guru Pendidikan Agama Islam - Syariva 'Aini, Risdoyok, Junaidi

DOI: https://doi.org/10.31004/edukatif.v3i6.1645

positif dan signifikan antara Pengalaman Mengajar terhadap Kinerja Guru PAI SD Kota Padang Panjang sebesar $26,73 \%$.

Dari uraian di atas dapat disimpulkan bahwa Pengalaman Mengajar berkontribusi signifikan sebesar 26,73\% terhadap variabel Kinerja Guru PAI SD Kota Padang Panjang. Dengan demikian dapat diartikan bahwa Kinerja Guru PAI SD Kota Padang Panjang sebesar 26,73\% ditentukan oleh Pengalaman Mengajar dan sisanya $73,27 \%$ ditentukan oleh faktor lain yang belum teramati

\section{Hipotesis Kedua}

Hipotesis kedua adalah " Keterampilan Mengajar berkontribusi secara positif dan Signifikan terhadap Kinerja Guru PAI SD Kota Padang Panjang”. Untuk menguji hipotesis ini digunakan analisa korelasi dan regresi sederhana. Pengujian hipotesis ini dilakukan dengan menggunakan hipotesa sabagai berikut :

$H_{0} \quad=$ Tidak terdapat kontribusi yang positif dan signifikan antara Keterampilan Mengajar terhadap Kinerja Guru PAI SD Kota Padang Panjang

$H_{l} \quad=$ Terdapat kontribusi yang positif dan signifikan antara Keterampilan Mengajar terhadap Kinerja Guru PAI SD Kota Padang Panjang.

Dasar pengambilan keputusan adalah bahwa diterima $\mathrm{H}_{0}$ jika nilai signifikasi > Alpha 0,05 atau $\mathrm{H}_{1}$ jika siknifikasi < Alpha 0,05.

Tabel 8

Rangkuman Hasil analisis Korelasi $\mathbf{X}_{2}-\mathbf{Y}$

\begin{tabular}{ccccc}
\hline Korelasi & $\mathrm{N}$ & Koefisien Korelasi (r) & Koefisien Determinasi $\left(\mathrm{r}^{2}\right)$ & Sig. \\
Ry2 & 39 & .351 & .1232 & $.000^{\mathrm{a}}$ \\
\hline
\end{tabular}

Dari hasil analisis diperoleh angka koefisien variabel Keterampilan Mengajar terhadap variabel Kinerja Guru PAI SD Kota Padang Panjang (ry2) sebesar 0.351. Angka korelasi ini menunjukkan bahwa kontribusi Keterampilan Mengajar terhadap Kinerja Guru PAI SD Kota Padang Panjang berkorelasi positif.

Selanjutnya tabel memperlihatkan angka koefisien determinasi sebesar 0.1232 dengan signifikasi sebesar 0.000. Sesuai dengan pengambilan keputusan di atas maka $\mathrm{H}_{0}$ ditolak dan $\mathrm{H}_{1}$ diterima. Ini berarti terdapat kontribusi yang positif dan signifikan antara Keterampilan Mengajar terhadap Kinerja Guru PAI SD Kota Padang Panjang dengan besar hubungannya adalah 12,32\%.

\section{Hipotesis Ketiga}

Dalam penelitian ini hipotesis ketiga yang diajukan adalah "Pengalaman Mengajar dan Keterampilan Mengajar secara bersama-sama berkontribusi Positif dan signifikan terhadap Kinerja Guru PAI SD Kota Padang Panjang”. Pengujian terhadap hipotesis dilakukan dengan analisis korelasi dan model regresi berganda (multivariat) antara variabel Pengalaman Mengajar $\left(\mathrm{X}_{1}\right)$ dan variabel Keterampilan Mengajar $\left(X_{2}\right)$ dengan variabel terikat Kinerja Guru PAI SD Kota Padang Panjang $(Y)$. Persamaan regresi yang dikemukakan adalah $\hat{Y}=b_{o}+b_{1} X_{1}+b_{2} X_{2}$. Pada Tabel 27 ditampilkan korelasi antara variabel terikat dengan variabel bebas secara bersama-sama.

Tabel 9

Rangkuman Hasil Analisis Korelasi Ganda Antara Variabel $X_{1}$, dan $X_{2}$ dengan $Y$

\begin{tabular}{ccccc}
\hline Korelasi & $\mathrm{N}$ & Koefisien Korelasi ( $\mathrm{r})$ & Koefisien Determinasi $\left(\mathrm{r}^{2}\right)$ & Sig. \\
Ry1-2 & 39 & .752 & .5655 & $.000^{\mathrm{a}}$ \\
\hline
\end{tabular}

Pada Tabel 4.17 di atas dapat dilihat bahwa besarnya harga koefisien korelasi ganda antara variabel $X_{I}$, dan $X_{2}$ dengan $Y$ (Ry.1.2) sebesar 0.752 dengan taraf signifikansi $($ Sig. $=0,000)<0,05$. Hal ini menunjukkan bahwa Pengalaman Mengajar $\left(\mathrm{X}_{1}\right)$ dan Keterampilan Mengajar $\left(X_{2}\right)$ mempunyai kontribusi yang signifikan terhadap Kinerja Guru PAI SD Kota Padang Panjang $(Y)$.

Berdasarkan hasil pengujian di atas hipotesis ketiga yang menyatakan bahwa "Pengalaman Mengajar dan Keterampilan Mengajar secara bersama-sama berkontribusi positif dan signifikan terhadap Kinerja Guru 
5124 Kontribusi Pengalaman Mengajar dan Keterampilan Mengajar terhadap Kinerja Guru Pendidikan Agama Islam - Syariva 'Aini, Risdoyok, Junaidi

DOI: https://doi.org/10.31004/edukatif.v3i6.1645

PAI SD Kota Padang Panjang” telah teruji secara empiris dan dapat diterima pada taraf kepercayaan 95\%. Besarnya hubungan adalah 0. 5655. Hal ini berarti bahwa variabel Pengalaman Mengajar dan Keterampilan Mengajar secara bersama-sama dapat memprediksi Kinerja Guru PAI SD Kota Padang Panjang sebesar $56.55 \%$ sisanya $43.45 \%$ diperkirakan berasal dari variabel yang belum diamati.

\section{KESIMPULAN}

Kontribusi pengalaman mengajar guru pendidikan Agama Islam SD se kota Padang Panjang sebenar 0.517dengan koefisien determinasi sebenar 0.2673 atau $(26,73 \%)$ melihat dari presentase ini bisa dikatakan kinerja guru sangat berdampak baik bagi kemajuan pendidikan di kota Padang Panjang. Sedangkan keterampilan mengajar menunjukkan 0.351 dengan koefisien determinasi sebear 0.1232 atau (112.32\%) bisa dikatakan keterampilan mengjaar yang baik akan berdampak terhadap kinerja guru. Kemudian melihat dari keterkaitan antara pengalaman mengajar dengan keterampilan mengajar sebenar 0.752 dengan koefisien determinasi sebesar 0.5655 atau (56.55\%). Hal ini menunjukkan bahwa untuk meningkatkan Kinerja Guru Pendidikan Agama Islam SD se Kota Padang Panjang dapat dilakukan melalui peningkatan pengalaman Mengajar bersamaan dengan perbaikan Keterampilan Mengajar.

\section{DAFTAR PUSTAKA}

Abdul Rouf dan Lufita Raghda. (2018). Peranan Guru dalam Implementasi Kurikulum 2013 di Madrasah Ibtidaiyah Negeri 1 Jombang. Sumbula, 903-926.

Ahmad, S. (2014). Problematika Kurikulum 2013 dan Kepemimpinan Intruksional Kepala Sekolah. Jurnal Pencerahan, 98.

Ariani, N. F., S'dijah, C., dan Subandi. (2016). Penerapan Model Pembelajaran Inquiry Terbimbing pada Materi Pecahan Sederhana Kelas III SD Prosiding Seminar Nasional Pendidikan Dasar 2016 Peningkatan Kualitas Pendidikan Dasar dalam Menghadapi Daya Saing Regional (ASEAN). 608-615.

Bahrudin Ardi, A. M. (2013). Penerapan Metode Inkuiri Untuk Meningkatkan Kualitas Pembelajaran IPA Pada Siswa Kelas V SDN 5 Mayonglor Kabupaten Jepara. Universitas Negeri Semarang: Doctoral Dissertation.

Joyce, B. C. (2009). Model of Teaching (Terjemahan). Yogyakarta: Pustaka Pelajar.

Joyce, B., Calhoun, E., \& Weil, M. (2009). Model of Teaching (Terjemahan). Yogyakarta: Pustaka Pelajar.

Kemendikbud. (2014). Permendikbud No. 103 tentang pedoman pelaksanaan pembelajaran. Jakarta: Kemendikbud.

Kristian, Y., \& Chaerul, M. (2010). Analisis Awal Implementasi Tempat Pengolahan Sampah Terpadu.

Lufita, A. R. (2018). Peranan Guru dalam Implementasi Kurikulum 2013 di Madrasah Ibtidaiyah Negeri 1 Jombang. Sumbula, 903-926.

Madjid, A. (2014). Pembelajaran Tematik Terpadu. Bandung: Remaja Rosdakarya.

Meinita, M. D. N., Marhaeni, B., Winanto, T., Jeong, G. T., Khan, M. N. A., \& Hong, Y. K. (2013). Comparison of agarophytes (Gelidium, Gracilaria, and Gracilariopsis) as potential resources for bioethanol production. Journal of applied phycology, 25(6), 1957-1961.

Mulyasa. (2008). Implementasi Kurikulum Tingkat Satuan Pendidikan. Bandung: PT Bumi Aksara.

Mulyasa, E. (2013). Pengembangan dan Implementasi Kurikulum 2013. Bandung: PT Remaja Rosdakarya.

Nurjanah, N. (2016). Peningkatan Hasil Belajar IPA Dengan Menerapkan Metode Inkuiri Siswa Kelas V SD Negeri 68 Kec. Bacukiki Kota Parepare. Publikasi Pendidikan, 107-110.

Ruslamiarti, F. R. (2013). . Hubungan Gaya Belajar dengan Hasil Belajar Bahasa Indonesia Siswa Kelas 5 SDN 17 Kota Bengkulu, 30. 
5125 Kontribusi Pengalaman Mengajar dan Keterampilan Mengajar terhadap Kinerja Guru Pendidikan Agama Islam - Syariva 'Aini, Risdoyok, Junaidi

DOI: https://doi.org/10.31004/edukatif.v3i6.1645

Sanjaya. (2010). Strategi Pembelajaran Berorientasi Standar Proses Pendidikan. Jakarta: Kencana Prenada Media Group.

Susanto, A. (2013). Teori Belajar dan Pembelajaran di Sekolah Dasar. Jakarta: Prenada Media Group.

Undang-Undang Republik Indonesia No. 20 Tahun 2003 tentang Sistem Pendidikan Nasional. (n.d.). Jakarta: Departemen Pendidikan Nasional Republik Indonesia.

Widyastuti, F. P. (2018). Peningkatan Hasil Belajar Siswa Kelas 4 SD Melalui Model Pembelajaran Inquiry Learning. Jurnal Kiprah, 1-13. 